\title{
New Growth Regulator "Ecostym" in Arable Farming of Ukraine
}

\author{
Mykhaylo Vasylenko, Maryana Draga* \\ The Institute of Agroecology and Environmental Management of NAAS of Ukraine, 12, Metrologichna str., Kyiv, 03143, Ukraine \\ *Corresponding Author: m_draga@hotmail.com
}

Copyright (C) 2014 Horizon Research Publishing All rights reserved.

\begin{abstract}
In field and laboratory studies the impact of new biological substances on agricultural crops was examined. The dependences of yields and product quality from the implementation of the biological substances Emistym and Ecostym were shown. Using of "Ecostym" shows high biological and agroecological efficiency on gray forest soils. Biological substances caused significant increasing of the yield, contents of protein, gluten and fat in agricultural products of such agricultural crops as spring wheat, maize, soybean, rapeseed and sunflower.
\end{abstract}

Keywords Growth Regulator, Crop, Yield, Product Quality, Emistym, Ecostym

\section{Introduction}

The application of biological and microbiological substances and fertilizers makes a significant contribution to the increasing of productivity of agriculture plants and quality of products. There are simple, affordable and cost-effective substances of natural origin, which caused increasing of crop yields [1-3]. The use of environmentally friendly plant growth regulators contributes to the development of useful soil microorganisms, improves soil fertility - the ability to deliver accumulated nutrients to plants and retain moisture and air [4,5]. The purpose of research is to study the impact of a new biological substance Ecostym on the yield and quality of crops.

\section{Materials and Methods}

Growth Regulator (GR) Ecostym is a hydroalcoholic solution of analogues of natural plant hormones (auxins, cytokinins and gibberellins), of amino acids, carbohydrates, vitamins, fat acids, trace elements and other biologically active substances which are prepared from the metabolic products of endophytic fungi from roots of Ginseng (Panax ginseng L.). This substance has the following properties: improves germination of seeds, plant photosynthesis rates, stimulates root formation, growth and development of plants, improves immunity to diseases of plants, increases the protein, sugars and vitamins content and stimulates flowering of plants. Biological product Ecostym is an analog of Emistym. Growth Regulator Emistym is produced in vitro in the Institute of Bioorganic Chemistry and Petrochemistry of the Academy of Science of Ukraine from the same raw materials (products of metabolism of epiphytes of the roots of Panax ginseng L. and Hippophao rhamnoides L.) and officially registered in Ukraine. Ecostym has slightly different ratios of the components in compare with Emistym.

Field experiments were conducted in vegetations of 2007-2010 years with spring wheat (Triticum aestivum L.) of cultivar "Colectyvna 3", soybean (Glycine max L.) of cultivar "Gorlytsya", maize (Zea mays L.)of 1st generation hybrid "Goverla", rapeseed (Brassica napus L.) of cultivar "Magnat", sunflower (Helianthus annuus L.) of cultivar "Kharkiv 7". The gray forest soil of the experimental field of the Institute of Agroecology and Environmental Management of NAAS had the following agrochemical characteristics: humus content $-1.18 \%$, hydrolyzed nitrogen by Cornfield $-64-86 \mathrm{mg} / \mathrm{kg}$, available phosphorus $-110-140$ $\mathrm{mg} / \mathrm{kg}$, exchangeable potassium $-70-110 \mathrm{mg} / \mathrm{kg}$, hydrolytic acidity $-1.34 \mathrm{mEq} .100 \mathrm{~g}$ of soil, $\mathrm{pH}-4.8-5.1$.

In field experiments in variants with treatment of seeds before sowing by Growth Regulators the seeds of cultivated plants were treated with Ecostym in doses of 10-12.5 ml/kg, $20-25,40-50$, and $75 \mathrm{ml} / \mathrm{kg}$, in variants with spraying by GRs crops were treated with the preparation in a doses of $12.5,25,40-50,75$ and $100 \mathrm{ml} / \mathrm{ha}$. Schemes of the experiments included control variant (the background with the using of nitrogen $(\mathrm{N})$, phosphate $(\mathrm{P})$ and potash $(\mathrm{K})$ fertilizers in different doses and standard variant (background with NPK fertilizers + treatment of Emistym in a dose of $10 \mathrm{ml}$ for a preliminary treatment of 1 ton of seeds, as well as by spraying 1 hectare of crops). For spring wheat of cultivar "Colectyvna 3" was used as background $\mathrm{N}_{60} \mathrm{P}_{60} \mathrm{~K}_{60}$, the for soybean of cultivar "Gorlytsya" $\mathrm{N}_{45} \mathrm{P}_{60} \mathrm{~K}_{60}$, for maize of 1 st generation hybrid "Goverla" $\mathrm{N}_{120} \mathrm{P}_{90} \mathrm{~K}_{90}$, for rapeseed of cultivar "Magnat" $-\mathrm{N}_{60} \mathrm{P}_{60} \mathrm{~K}_{60}$, for sunflower of cultivar "Kharkiv 7" $-\mathrm{N}_{60} \mathrm{P}_{60} \mathrm{~K}_{60}$.

The size of field plots was $40-50 \mathrm{~m}^{2}$, the experiments was 
hold in 4-multiple biological repetitiveness [6]. Crops spraying by GR were conducted in variants where the seeds were treated by Ecostym as well as in variants with no pre-sowing treatment of seeds. Spraying by aqueous solution of GR of spring wheat was carried out in the end of stooling stage - the beginning of stem elongation stage, of corn and sunflower - in the phase of 4-6 leaves, of soybean and rapeseed - in the budding stage. Spraying the crops on experimental plots was carried out in the morning when the air temperature is not above $21^{\circ} \mathrm{C}$ by knapsack sprayer or with the help of tractor-mounted sprayer. Consumption of $\mathrm{RG}$ solution is $250 \mathrm{l} / \mathrm{ha}$.

Nitrate reductase activity in wheat leaves was determined in vivo by the method of Mulder. The Kyedal's method was used for determination of total content of nitrogen. The grain quality was evaluated with an "Infrapid" device (USA), which allows us to measure the protein content in grain precisely. Data were analyzed using repeated measures analysis of variance. The statistical processing of our data was carried out using the dispersion analysis. All evaluations were made using an alpha level of 0.05 .

\section{Results and Discussions}

The field studies on gray forest soils have shown high efficiency of Ecostym as well as Emistym in variants with all crops. Due to the results of the field studies the optimal doses of application of plant Growth Regulator Ecostym on all crops species were established. The optimum rate of consumption of the Ecostym for all crops except corn is 20-25 $\mathrm{ml}$ per 1 ton of seeds and the same dose for spraying of
1 ha of crops; for corn - 25-40 $\mathrm{ml}$ for both type of treatment. In the first part of our work we studied the physiological influence of these Growth Regulators on the nitrate-reducing ability of leaves and on the total nitrogen content of spring wheat (Triticum aestivum L.) of cultivar "Colectyvna 3" (treatment - spraying of plants).

The analysis of the dynamics of total nitrogen accumulation in the flag leaf during the 1-st year vegetation shows that the GRs promote the nitrogen content increase (Figure 1).

Because the regulators show cytokinin activity, they can induce the synthesis of nitrate reductase [7] regardless of the quantity of substrate and promote launching of the synthesis of various enzymes involved in biosynthesis of RNA and proteins [8,9]. It is known that wheat is related to an intermediate group of plants in which the nitrate reductase activity is distributed between roots and leaves [10].

According to our data, Emistym and Ecostym stimulated the increase of the level of induced nitrate reductase activity in the flag leaf and particularly in its sheath. Sheath, that is the leaf basis, which envelops the intercalary meristem zone, appeared to be the place of the most intensive nitrate reductase activity.

The most significant impact of Emistym and Ecostym on the nitrate reductase activity was observed in the 2-nd year vegetation (Figure2), which was characterized by high temperatures during the stage of earing (daily temperature varied from 20 to $25^{\circ} \mathrm{C}$, the maximum reached $38^{\circ} \mathrm{C}$ ) and moisture deficiency. As already mentioned, the highest nitrate reductase activity was detected in sheath.



Figure 1. Influence of physiologically active substances on total nitrogen content in flag leaf of spring wheat cult."Colectyvna 3", \% (1-st year's vegetation) 


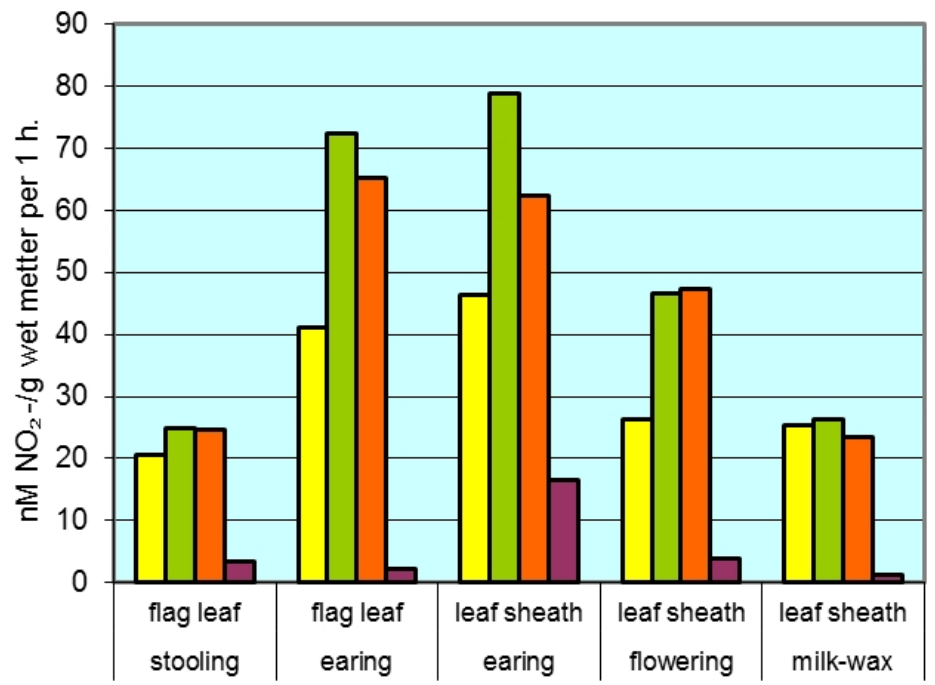

Figure 2. Influence of physiologically active substances on nitrate reductase activity in flag leaf and sheath of spring wheat cult. "Colectyvna 3" (nM $\mathrm{NO}_{2}{ }^{-} / \mathrm{g}$ of wet matter per 1 hour), 2-nd year's vegetation

Table 1. Yield ( $\mathrm{t} / \mathrm{ha}$ ) and quality of grain of crops by using of Growth Regulators "Emistym" (Standard) and "Ecostym"(average data for vegetations of 2007-2010 years.)

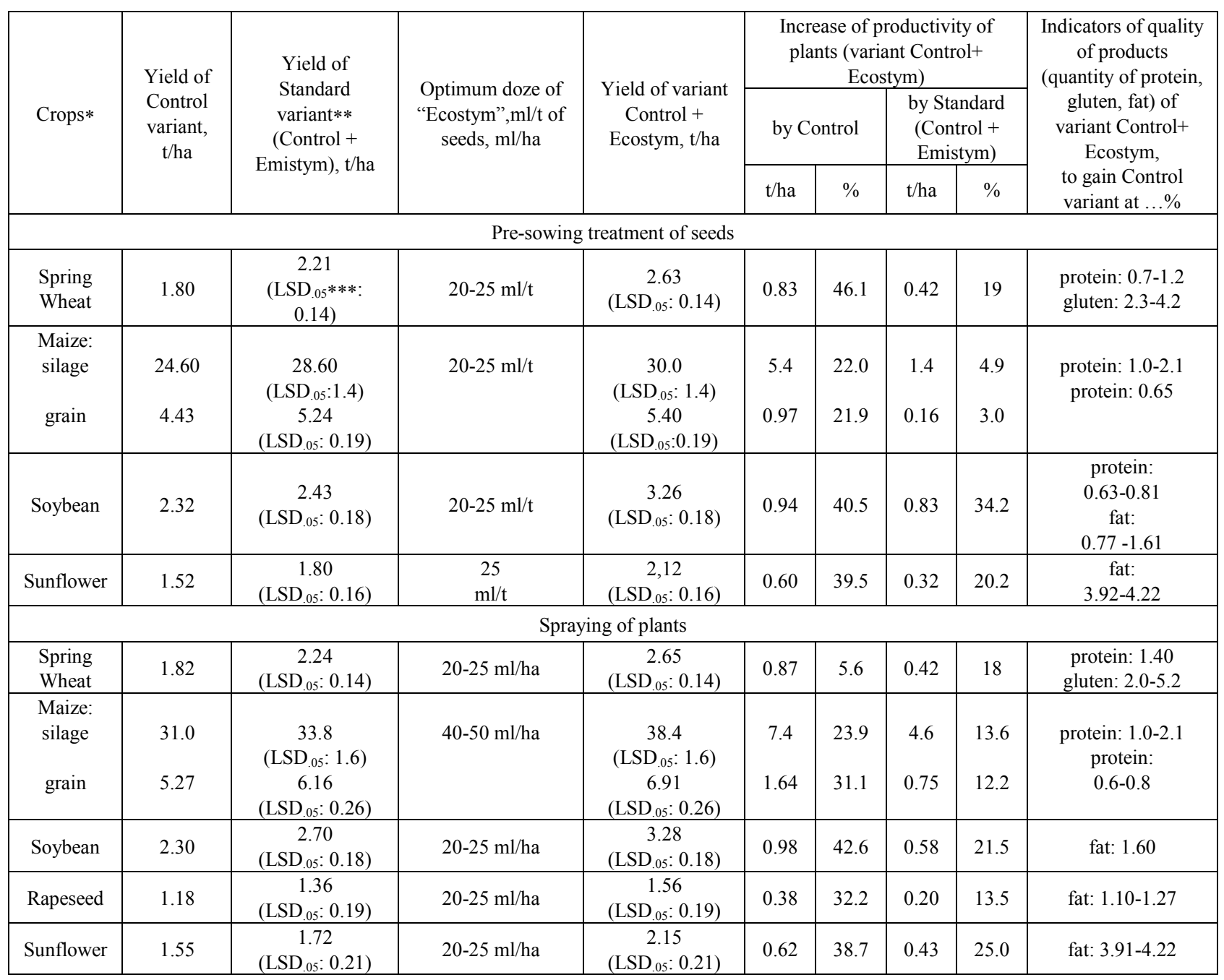

* Spring Wheat (Triticum aestivum L.) of cultivar "Collectivna 3" $\left(\mathrm{N}_{60} \mathrm{P}_{60} \mathrm{~K}_{60}\right)$; Soybean (Glycine max $\mathrm{L}$.) of cultivar "Gorlytsya" $\left(\mathrm{N}_{45} \mathrm{P}_{60} \mathrm{~K}_{60}\right)$; Maize (Zea mays L.) of 1-st generation hybrid "Goverla" ( $\left.\mathrm{N}_{120} \mathrm{P}_{90} \mathrm{~K}_{90}\right)$; Rapeseed (Brassica napus L.) of cultivar "Magnat" $\left(\mathrm{N}_{60} \mathrm{P}_{60} \mathrm{~K}_{60}\right)$;

Sunflower (Helianthus annuus L.) of cultivar "Kharkiv 7" ( $\left.\mathrm{N}_{120} \mathrm{P}_{90} \mathrm{~K}_{90}\right)$;

** for Standard variant (Control + Emistym) concentration of Emistym for pre-sowing treatment of seeds was $10 \mathrm{ml} / \mathrm{t}$; for spraying of plants $-10 \mathrm{ml} / \mathrm{ha}$; *** $\mathrm{LSD}_{.05}$ - Fisher's Least Significant Difference ( alpha significance level of 0.05). 
The most effective among the regulators was Emistym during the stage of earing (the enzyme activity increased by $76.7 \%$ ). The nitrate reductase activity in sheath of the Ecostym-treated plants at the stage of earing rose by $59.0 \%$ compared to the control plants.

In the second part of our work we studied the influence of GRs on grain productivity and quality of crops. Table 1 summarized the increase in yield as well as the increase of protein content in grain every year for crops treated with growth regulators. The application of pre-sowing treatment of spring wheat increased the yield by $0.83 \mathrm{t} / \mathrm{ha}$, protein content by $1.2 \%$, gluten by $4.2 \%$. Spraying of spring wheat by Ecostym increased the grain yield by $0.87 \mathrm{t} / \mathrm{ha}$, the protein content by $1.40 \%$ and gluten content by $2.0-5.2 \%$.

The treatment of corn seeds by growth regulator Ecostym before sowing increased silage yield by $5.4 \mathrm{t} / \mathrm{ha}$, the protein content in the silage - by $1.0-2.01 \%$, corn grain yield by 0.97 $\mathrm{t} / \mathrm{ha}$, the protein content of grain by $0.65 \%$. Spraying the corn plants by RG increased the yield of silage by $7.4 \mathrm{t} / \mathrm{ha}$, the protein content in silage by $2.1 \%$, the corn grain yield by $1.64 \mathrm{t} / \mathrm{ha}$, grain protein content by $0.8 \%$.

Treatment of soybean seeds by Ecostym before sowing achieved an increase of yield by $0.94 \mathrm{t} / \mathrm{ha}$, the protein content by $0.63-0.81 \%$, fat by $0.77-1.61 \%$. Spraying of soybean by Ecostym caused increasing of yield by $0.98 \mathrm{t} / \mathrm{ha}$ and the fat content by $1.6 \%$. The use of growth regulator for treatment of sunflower seeds increased crop yield by $0.6-0.74 \mathrm{t} / \mathrm{ha}$, fat content in seeds by $3.92-4.22 \%$. Treatment of sunflower by RG spraying increased the seed yield by $0.62 \mathrm{t} / \mathrm{ha}$, the fat content in seeds by $3.92-4.11 \%$. Spraying the rapeseed by Ecostym increased the seed yield by $0.38 \mathrm{t} / \mathrm{ha}$, the fat content increased by $3.91-4.22 \%$.

Thus, the using of the growth Regulators Ecostym as well as Emistym (used as standard) increased the yield of agricultural crops such as spring wheat of cultivar "Collectivna 3", soybean of cultivar "Gorlytsya", corn of 1st generation hybrid "Goverla", rapeseed of cultivar "Magnat" and sunflower of cultivar "Kharkiv 7". The use of GRs improves the quality of agricultural products for all investigated species of plants.

\section{Conclusion}

Our results show that treatment with new Growth Regulators promotes increase in the grain yield and quality, improves adaptive abilities of wheat by enhancing the activity of nitrate-reducing system, which is proved by increase in the grain protein content. Pre-sowing treatment of crops by Growth Regulator Ecostym achieved an increase of corn grain yield by $21.9 \%$, yield of silage by $22 \%$; yield of soybean increased by $40.5 \%$, yield of sunflower increased by $48.7 \%$. Spraying of spring wheat by Ecostym caused increasing of grain yield by $37 \%$; for corn grain yield - by $31.1 \%$, for silage yield - by $23.9 \%$; seeds yield of soybean increased by $42.6 \%$; for rapeseed - by $32.2 \%$.

The use of ecologically safe growth regulators as a means for biologization of new technologies to increase the grain culture productivity and extend the employment of the new kinds of the biological approaches to plant protection, especially under unfavorable environment conditions is very urgent in modern sustainable agriculture. Growth regulators Ecostym as well as Emistym can be used with high efficiency for a pre-sowing seed treatment and for spraying of crops during vegetation in arable farming of Ukraine.

\section{REFERENCES}

[1] F. L. Kalinin. Application of growth regulators of plants in the agricultural economy, Urozhay, Kyiv, 1989.

[2] S. P. Ponomarenko. Growth regulators of plants, Logos, Kyiv, 2003.

[3] S. P. Ponomarenko. Bioregulation of plants growth and development. Growth Regulators in crop farming. In Book: Bioregulation of microbial-plant systems, Nichlava, Kyiv, 251-351, 2010.

[4] V. K. Yavors'ka. Growth regulators of natural origin and their applications, Logos, Kyiv, 2006.

[5] V. V. Morhun. Problem of plants growth regulators in the world and it decision in Ukraine Physiology and Biochemistry of Plants, Vol.34, No.5, 317-375, 2003.

[6] B. A. Dospekhov. Methods of Field Experiment, Agropromizdat, Moskow, 1985.

[7] V. V. Kuznetsov, Kuznetsov V1.V. and Kulayeva O.N., Biochemistry, Moscow, Vol.44, No.4, 684-687, 1979.

[8] N. L. Klyachko, L. A. Yakovleva and F. M. Shakirova. Regulators of Growth and Development in Plants, Nauka, Moscow, 2008.

[9] V. M. Troyan, V. K. Yavorska, S. P. Ponomarenko. Physiology and Biochemistry of Cultural Plants, Kyiv, No.5, 10-16, 1998.

[10] S. F. Izmaylov. Nitrogen methabolism in plants, Vysshaya shkola, Moscow, 2009. 